\title{
The Stolen Generations and genocide: Robert M anne's In denial: the Stolen Generations and the Right
}

\author{
Bain Attwood
}

In recent years many A ustralians have been troubled over two words or terms, the Stolen Generations and genocide, and no more so than when they have appeared in tandem, as they did in the report of the Human Rights and Equal Opportunity Commission's inquiry into the separation of A boriginal children, Bringing Them $\mathrm{H}$ ome, ${ }^{1}$ and the inquiry that gave rise to it. ${ }^{2}$ Subsequently many conservatives have increased their attacks upon so-called black armband history and particularly the Stolen Generations narrative. ${ }^{3}$ This assault gathered momentum during 1999 and 2000, eventually provoking the political commentator and historian Robert Manne to pen In denial: the Stolen Generations and the Right, an essay in which, to quote the publicists for this new venture in Australian publishing, the A ustralian Quarterly Essay, he sets out to 'demolish' these critics and their 'demolition' of the history presented by Bringing Them Home. ${ }^{4}$

Manne, as he makes abundantly clear throughout In denial, is not only convinced there is 'a growing atmosphere of right-wing and populist resistance to discussion of historical injustice and the Aborigines' in Australia today; he also believes there has been 'an orchestrated campaign' by a 'small right-wing intelligentsia' to 'change the moral and political balance ... with regard to the A boriginal question as a whole' and 'the issue of the Stolen Generations' in particular. Manne al so fears this has been effective, creating 'scepticism and outright disbel ief' among 'a highly receptive audience'. ${ }^{5}$

1. This was not unprecedented, however. For instance, in the early 1980s the historian Peter Read discussed the removal of children and raised the question of whether this could be regarded as a case of genocide - ' I ... hope that in the next decade the context of systematic dispersal will become better known and understood. Such terms as 'invasion' and 'attempted genocide', which still appear to stick the typewriters of some historians and others, will no longer be avoided' (1983a: 32) - while some of the critical responses to the 1983 documentary film Lousy Little Sixpence (which focused to a large degree on child removal) referred to genocide (File for Lousy Little Sixpence, Australian Film Institute Research and Information Centre, Melbourne).

2. See Attwood 2001: 258. For a consideration of earlier attacks on what has been called the new Australian history, see Attwood 1996 and Curthoys 1997.

3.

See Attwood 2000 and 2001.

4. Black Inc 2001; Craven 2001: iv. 
Manne's defence of the Commission's inquiry and its report proceeds in three ways. First, he seeks to expose the weaknesses in the conservative attack upon it by revealing how much of what they say is flawed. Second, he reasserts its value: the inquiry 'gave the victims of child removal a public voice', and the report enabled nonIndigenous A ustralians 'to hear, for the first time, the voices of the victims and their stories of abuse, bewilderment, disorientation, loneliness and pain' and so grasp what 'they had previously failed to understand or even to see'. ${ }^{6}$ Third, he concedes the weaknesses in this historical account (which has led critics of the Stolen Generations narrative to claim he has done a 'turnaround' and others to assert he has done an 'about face' $)^{7}$ and attempts to address these. There was, he says, 'a gulf between the seriousness of the moral issues involved and the thinness of the historical grasp'. ${ }^{8}$ Most importantly, we need to reconsider the report's representation of the manner in which children were separated, revise its estimates of the number of children separated, and refine its contention that this amounted to genocide. Children were separated in 'a wide variety of circumstances' and under a range of laws; placed in many different forms of care; variously treated, and suffered varying degrees of separation from their parents and kin. In other words, they were not all forcibly removed from happy homes under racially discriminatory legislation, thrust into special institutions, cruelly used and denied contact with their families. Indeed, Manne insists, hardly any generalisation regarding those who were separated 'holds good'. ${ }^{9}$ We should also acknowledge, he contends, that Bringing Them $\mathrm{H}$ ome 'greatly exaggerated the numbers of children involved': its claim that as many as one in three children were separated is 'certainly wrong'; instead, an Australian Bureau of Statistics 1994 survey finding that one in ten A boriginal children were separated between 1910 and 1970 is 'far more soundly based'. As for the numbers of children separated, it is 'probable that between 20000 and 25000 A boriginal children were separated from their families between 1910 and 1970', a much lower figure than the oft-quoted figure of 100000 or even the other, commonly used estimate of 50000 . But this, Manne emphasises, is 'far from a trifling sum' because of 'the ripple effect of the removals on parents, siblings and extended families'. ${ }^{10}$ Finally, he argues 'the plausibility of the discussion of the relationship between child removal and genocide in Bringing Them Home was ... weakened' by its failure 'to distinguish with sufficient clarity between [two] chapters of child removal', that of 'the pre-war ... age of eugenics, biological absorption and racial engineering ... [and that of the postwar era of] social and cultural assimilation': the former, which he identifies with two important administrators of A boriginal affairs in the inter-war period, AO Neville in Western Australia and Cecil Cook in the Northern Territory, was 'driven by genocidal intentions', the latter, which he associates with Paul Hasluck, Commonwealth Minister for the Territories 1951-63, was not. ${ }^{11}$

5. Manne 2001a: 4, 6, 31, 42, 44, 51, 67.

6. Manne 2001a: 29, 34, 104. See also Manne 1998: 35.

7. See, for example, Bolt 2001, Brunton 2001 and Slattery 2001.

8. Manne 2001a: 29.

9. Manne 2001a: 2, 28.

10. Manne 2001a: 25, 27, 29.

11. Manne 2001a: 30, 38, 40. 
Much of Manne's attack on the conservative critics of the Stolen Generations narrative is persuasive. He readily demonstrates many of their criticisms of Bringing Them Home are simply untenable, characterised as they are by poor reasoning, interpretive misconceptions, inadequate evidence and factual errors. ${ }^{12}$ More interestingly, Manne is also able to show the nature of some non-A boriginal testimony has, like that of the Stolen Generations, changed in various respects over time. He does this by considering a series of oral history interviews with senior Northern Territory patrol officers conducted in the early 1980s, before the Stolen Generations achieved the prominence they have come to have. 'A Imost all', he contends, 'expressed shame and regret at the policy they had been required to implement'. ${ }^{13}$ As such, their perspective forms a stark contrast to that of other 'old men' who, in a heightened atmosphere of personal and political attacks, feel wounded and have struck out at those they regard as their accusers.

In what amounts to his most telling consideration of such critics, Manne examines a man who belongs not to the generation of these elderly men but to that of the sons Douglas Meagher, who headed the Commonwealth's legal team in the Cubillo and Gunner case in the federal court (1996-2000), and whose father was chairman of the A borigines Welfare Board and Minister for Aboriginal Affairs in Victoria in the 1960s. Manne tells a story that suggests M eagher's investment in scrutinising the Stolen Generations narrative was informed by a desire to defend his father's honour and that this rendered him 'both prejudiced and blind' in important respects. In the course of addressing a Q uadrant seminar, 'Truth and Sentimentality', in September 2000, shortly after the Commonwealth's triumphant victory in the Cubillo and Gunner case, a sentimental Meagher attacked what he called an 'appalling slur' in Bringing Them $\mathrm{H}$ ome $-\mathrm{a}$ claim a holiday program for A boriginal children devised by the A boriginal singer and activist $\mathrm{H}$ arold Blair, and supported by, among others, Meagher's father, had entailed the permanent separation of A boriginal children from their parents. Meagher told his audience he could not 'believe that Harold Blair [an occasional visitor to Meagher's childhood home] would have lent his support to such a scheme; nor that [his] father would have done so'. This claim, he continued, was typical of the 'dreadful accusations ... against the men and women who formed and implemented the policies of that era'. ${ }^{14}$ And yet, Manne is able to show, by a careful discussion of historical evidence, there is some truth in Bringing Them H ome's account of this matter and that, like so many of the conservative attacks on the Stolen Generations narrative, Meagher's impassioned broadside does not rest on any research of the contemporary historical record.

Meagher's approach to the Stolen Generations has greater significance than this, however. Like Justice O'Loughlin, the presiding judge in the Cubillo and Gunner case, he is also, Manne suggests, a good example of a decent Australian who has a poor understanding of the nature of racism and who seems 'incapable of seeing the injustice done to the Aborigines' in the past. Racism, in the eyes of those like Meagher, merely consists of attitudes, beliefs or acts that treated A boriginal people as inferior and discriminated against them accordingly. This ignores, Manne convincingly argues, the

\footnotetext{
12. Manne 2001a: 35, 47-57, 67-71.

13. Manne 2001a: 42-4.

14. Manne 2001a: 86-90.
} 
ways in which an ostensibly benevolent welfarism was akin to racism. Echoing an argument previously made by Peter Read, ${ }^{15} \mathrm{M}$ anne points out that 'even among the kindest of human beings involved in the removal process, [there were] ways of thinking ... disfigured by the all-pervasive racism of the times'; few, if any Australians in the pre-war era could 'emancipate themselves' from 'racist ways of thought'. This, he argues, 'is probably the most important lesson [this history] has to teach - namely how almost no-one was able to see through the kind of racism' that underpinned the practice of removing A boriginal children from their families and communities. ${ }^{16}$ The evil lies, he seems to suggest, in the thinking and the attitu des of our forebears rather than some lack of moral sensibility (as is often claimed).

Manne's reassessment of Bringing Them $\mathrm{H}$ ome is both necessary and hel pful, all the more so because of his prominent role as a public commentator who has championed the Stolen Generations in recent years. As he points out, the Human Rights and Equal Opportunity Commission inquiry's claim that as many as one in three children were removed between 1910 and 1970 is quite untenable, while the 100000 is an entirely spurious figure, the result of a journalist's misunderstanding of an observation by Peter Read ${ }^{17}$ but then bandied about during the Commission's inquiry and repeated on a number of occasions since. ${ }^{18} \mathrm{M}$ anne could well be right that one in ten Aboriginal children were separated nationally (though one might doubt whether such a calculation furthers our understanding of the impact of removals on A boriginal communities given there were, as he acknowledges, ${ }^{19}$ such marked regional differences in government policies and practices regarding separation). Likewise, he is correct in pointing out Bringing Them Home tended to conflate 'separation' and 'forced removal' and so obscured the range of circumstances in which Aboriginal children were taken from their parents or kin, the various reasons for which they were separated, and the different experiences they later had. ${ }^{20}$

This said, there are several weaknesses evident in Manne's important essay. He weakens the force of his assessment of the conservative critics by becoming unduly polemical: he asserts rather than argues for or evidences his principal thesis - that there has been an orchestrated and effective right-wing campaign against the Stolen Generations narrative and this amounts to 'historical denialism'. There can be little doubt conservatives have been greatly troubled by the Stolen Generations history, and by historical scholarship in the area of Aboriginal history more generally, and have mounted many attacks upon this history-making, but it is questionable whether this amounts to a 'campaign' in the sense of a highly organised, tightly knit and well coordinated form of activity. Certainly, Manne does not make a persuasive case here, though there was an opportunity to do so. ${ }^{21}$ One should al so note, however, that the conservatives have their own, parallel 'conspiracy theory' regarding the so-called 'left-wing

15. Read 1983a: 30; 1983b: 20.

16. Manne 2001a: 78-9, 84, 92-3.

17. Edwards and Read 1990: xvii.

18. See Attwood 2001: 255-6.

19. Manne 2001a: 25-7.

20. See Attwood 2001: $207-10$, for similar criticisms of the Stolen Generations narrative produced in recent years. 
historians' whose work they attack, ${ }^{22}$ and both accounts of the other are overdetermined and so tend to be parodies.

Manne might have spent more time developing an analysis of what drives those he labels as 'right-wing'. (Only at the close of his essay does he offer some suggestions, the most important explanation being that '[e]ver since the early 1970s Australians have been struggling to come to terms with the crimes committed during the settlement of their country and with the ways in which the A borigines were treated by governments and society after the dispossession was complete') ${ }^{23}$ Consequently the nature of their broader project, inasmuch as the writings of this disparate group of conservatives could be said to have any single goal, is left unclear. Nor is it really evident why Manne accuses these critics of 'denialism'. Any discussions of this kind will invariably be conducted against the backdrop of the assault upon David Irving's infamous claims regarding the Holocaust (and the term has been used and misused a great deal recently), but Manne muddies the waters when he refers to 'an Australian version of historical denialism'. ${ }^{24}$ This obscures rather than clarifies what precisely these critics have done or are doing, and the grounds upon which and the reasons why they might be doing it.

The most important weaknesses in Manne's account lie, however, in his historical treatment of both the Stolen Generations narrative and genocide. First, his account of the emergence of the narrative is misleading; though there can be no doubt that this history only gained a large public audience as a result of Bringing Them $\mathrm{H}$ ome, knowledge of this past was much greater than Manne al lows. Beginning in the early 1980s, the separation of A boriginal children became the subject of much public history-making by the Stolen Generations themselves, historians, film-makers, curators, and so on, and had taken the form of autobiographies, family histories, academic studies, poetry, songs, films, exhibitions and so forth, which had penetrated the public real $\mathrm{m} .{ }^{25} \mathrm{M}$ anne barely mentions this and largely overlooks the academic studies done in the 1980s and early 1990s as well as the A boriginal autobiographies and oral testimonies published during the same period. Nor does he refer to more recent scholarly work, the most important of which is Anna Haebich's general history, Broken circles: fragmenting Indigenous families 1800-2000. As a result, he perpetuates a major misconception, shared by the critics of the Stolen Generations narrative (and nearly all public commentators): that Bringing Them H ome (and legal cases such as Cubillo and Gunner) constitutes the cornerstone of historical study and knowledge of the removal of Aboriginal children.

Second, Manne has not grasped the fact that the Stolen Generations narrative is not so much a history as it is a collective memory. This is, perhaps, unsurprising. Hehas little if any scholarly interest in understanding (and so representing) the process

21. For example, instead of savaging former cadet patrol officer, Colin Macleod, Manne might have more carefully researched the ways in which Macleod's 1997 memoir, Patrol in the D reamtime, was repeatedly (mis)used by the critics, including the Commonwealth government (2001a: 44-7, 108); note, however, that Manne's suggestion that Prime Minister John H oward 'invited Colin Macleod to Canberra to discuss A boriginal child removal' is incorrect.

22. Reynolds 2001.

23. Manne 2001c: 102-3.

24. Manne 2001a: 105

25. See Attwood 2000 and 2001 passim for a discussion of this. 
entailed in 'working up' a historical narrative - one suspects that, like the conservative critics, he thinks such an approach smacks of 'postmodernism' 26 - and he privileges 'top-down' rather than 'bottom-up' accounts of cultural and political change. There are a few signs in In denial that he now realises the narrative cannot be treated as a conventional history - for example, he observes that "the term "Stolen Generations" had come [to be] for A boriginal Australians ... a way of referring, in a kind of moral shorthand, to a common and collective tragedy' 27 - but his understanding of collective memory and its relationship to history remains quite limited. Consequently, he has become a rather puzzled and therefore confused champion of the Stolen Generations narrative.

Something of this is evident in his treatment of autobiographical testimony. He has come to realise this can be a highly problematic source, though his assertion in In denial that ' $[i] t$ could have defused much subsequent criticism if [the Human Rights and Equal Opportunity Commission inquiry] had more explicitly acknowledged in its report something anyhow obvious to commonsense, namely that ... the memories of some members of the Stolen Generations ... were likely to have been simplified and even distorted with the passage of time' ${ }^{28}$ is disingenuous. He failed to grasp this earlier, and even now his approach to historical sources that draw upon memory remains somewhat naive, as his treatment of aspects of Lorna Cubillo's story reveals. ${ }^{29} \mathrm{He}$ seems reluctant to accept the dangers of unduly relying on (auto)biographical sources; like Bringing Them $\mathrm{H}$ ome, he devotes considerable space in In denial to the telling of four personal stories of the Stolen Generations. 'The assessment of the arguments involved in [this debate] cannot take place in a vacuum', he asserts. 'Without stories, the understanding of child removal ... is in danger of becoming far too abstract and remote'. ${ }^{30}$ Like a recent retelling of Lowitja O'Donoghue's story by the journalist Stuart Rintoul, ${ }^{31}$ there can be no denying the emotional power of personal stories, ${ }^{32}$ nor that they have often been well told, but biography should not be asked or required to bear the burden of explanation traditionally shouldered by history. The cost of this erroneous expectation has been made plain by the narratives produced by both the HREOC inquiry and the Cubillo and Gunner case: it is one thing for A boriginal narrators to play the role of bearing witnesses, another to demand that their histories perform a task traditionally undertaken by historical research and analysis. Here Manne tells these stories but offers little by way of exegesis. ${ }^{33}$

In his treatment of genocide, Manne focuses on eugenicist policies of absorption, in particular those advocated by N eville and Cook. Recently Manne has remarked that

26. See republication of a section of Attwood 2000 under the heading 'Lies, Damned Lies and ... postmodernist historiography', Q uadrant, March 2001: 21.

27. Manne 2001a: 82.

28. Manne 2001a: 30, my emphasis.

29. Manne 2001a: 19-20. Manne also misconstrues some of Geral dine Briggs' testimony (2001a: 13) as a result of relying on Stuart's Rintoul oral history (1993). See Attwood 2001: 253 for a discussion of the latter.

30. Manne 2001a: 6.

31. Rintoul 2001.

32. At the launch of In denial in Mel bourne, 6 A pril 2001, several speakers praised what they called Manne's approach of 'the head' and 'the heart'.

33. Manne 2001a: 6-24. 
it was a statement of N eville's (to the first national conference of administrators of A boriginal Affairs in 1937) that first 'plunged [him] into serious study' of this country's Aboriginal past:

'A re we going', N eville asked, 'to have a population of one million blacks in the Commonwealth or are we going to merge them into our white community and eventually forget that there were any A borigines in Australia?'. Neville's rhetorical question struck me with the force of lightning. Was he really advocating a policy for the disappearance of the Aboriginal people? Was this not a clearly genocidal thought? ... I discovered that N eville's idea of merging or absorbing the so-called 'half-caste' A borigines into the European population by a process of encouraged inter-breeding had won the approval of the delegates to the conference. $^{34}$

Comments such as N eville's are undoubtedly striking, and they have a particular resonance for those familiar with the more or less contemporaneous history of $\mathrm{Nazi}$ Germany's persecution of the Jews. ${ }^{35}$ However, one can readily make a number of errors when they are one's point of departure and focus. First, these statements of intent can be mistaken for action(s). As Inga Clendinnen has noted in the course of discussing Manne's essay, '[i]ntentions matter' but so, too, do outcomes and 'the connections [between them] are not al ways evident'. ${ }^{36}$ Manne seems convinced Neville and Cook won broad acceptance for their eugenicist policies and were able to implement them, ${ }^{37}$ yet what Clendinnen would call a close reading of the historical record of actions does not support this claim. Manne not only posits a simple casual relationship between intentions and actions, however; he does little if anything to examine the nature of policymakers' and administrators' intentions, being inclined instead to reach (for) a moral judgement about individual historical actors or their actions rather than striving to understand broad and complex historical contexts. ${ }^{38}$

Manne also makes a mistake when he overlooks the deep and profound historical continuities between the thinking that underpinned the policies of (biological) absorption and (cultural) assimilation. Although there were differences, it is doubtful that they were truly 'fundamental'. ${ }^{39} \mathrm{H}$ asluck was, so to speak, a son of N eville; his approach to assimilation no more envisaged the long-term survival of a vibrant A boriginality than his predecessors did. ${ }^{40}$ By defining racism in the narrow (biological) terms that he does and by emphasising absorptionist policies as the primary example of genocide, Manne distracts attention from assimilation as a form of racism that was (and is) of much longer standing in Australia. Neville and Cook's proposals at the 1937 conference do not seem at all novel when placed in the context of the policies that various governments had al ready been pursuing, for example the NSW A borigines Protection Board's policy of 'dispersal'.

34. Manne 2001b. Elsewhere, Manne has written of this 1937 conference: 'If there exists a moreterrible moment than this in the history of the twentieth-century Australian state than the Canberra conference of A pril 1937, I for one do not know where it is to be discovered' (1998: 31).

35. See, for example, Moses 2001.

36. Clendinnen 2001: 26.

37. Manne 2001a: 38-40, 64-5, 78.

38. Krygier 2001.

39. Manne 2001a: 40

40. See, for example, Rowse 1989. 
If we are to consider seriously the question of genocide in relation to the removal of A boriginal children, we can only do so by exploring the broader historical circumstances in which it occurred, paying particular attention to the assumptions of governments and settler Australians regarding the future of Aboriginal people and to the nature of Commonwealth and State policies from the turn of the century (when discriminatory legislation was passed by nearly all legislatures) to the end of the 1960s (when assimilation was supposedly abandoned as a goal) and to their relationships to A boriginal people which was itself the product of the relationships between $A$ borigines and settlers on the colonial frontier and the later, ongoing dispossession and displacement. There is a considerable body of historical evidence which suggests that across the first 50 or more years of last century governments and/ or the majority of Australians either: (i) anticipated the demise of 'the Aborigines' or Aboriginal communities and A boriginality because they assumed that the former were 'a dying race' or/ and that the latter was incompatible with modern Australian society; or/ and (ii) wished that Aborigines would disappear because they held that Aboriginality was worthless and its bearers an embarrassing presence; or/ and (iii) implemented policies that aimed to destroy Aboriginality by breaking up Aboriginal families or communities and 'dispersing' A borigines into the general community where they were to be 'merged' because it was held that the future was 'white' and this was 'for their own good'; or/ and (iv) pursued policies that did not aim to break up Aboriginal communities and destroy A boriginality but which nevertheless had, they knew, this effect. The outcomes of each of these phenomena was, no doubt, neither simple nor transparent, but each implies a certain kind of relationship between Indigenous and non-Indigenous Australians that undoubtedly had serious consequences for Aboriginal people, whether or not these were necessarily intended or even clearly envisaged by settler Australians or their governments. ${ }^{41}$

If this is a fair summary of attitudes to Aboriginal people or Aboriginality and approaches in A boriginal affairs over much of the twentieth century, we can ask how we might conceptualise and, thereby, understand them. In particular, is it helpful to consider in terms of genocide? As Manne observes in his essay, '[f]or a people that has not yet come to terms with the extremity of what it has done to the indigenous population of Australia, discussion of genocide and the Stolen Generations was never going to be easy'. ${ }^{42}$ Indeed, as the response to this essay has again revealed, there is a rush to dismiss consideration of genocide in Australia even before arguments have been or can be properly mounted or presented. There are reasons for this other than or further to the one Manne suggests, most importantly the way in which genocide is commonly imagined or understood. In considering Manne's discussion of genocide and the Stolen Generations, Clendinnen has commented:

I am reasonably sophisticated in various modes of intellectual discussion, but when I see the word 'genocide' I still see Gypsies and Jews being herded into trains, into pits, into ravines, and behind them the shadowy figures of Armenian

41. Here I am drawing on the important essay by Tony Barta in which he urges an approach to genocide that replaces the conceptual emphasis upon intention (or purpose, motive, policy or planning), particularly those of individuals but also of the state, with one that focuses upon 'sets of relationships' in any given society (1987: 238-9).

42. Manne 2001a: 41. 
women and children being marched into the desert by armed men. I see deliberate murder: innocent people identified by their killers as a distinctive entity being done to death by organised authority. ${ }^{43}$

In other words, though she acknowledges the point (which Manne among others have made) that the 1948 United Nations Convention on the Prevention and Punishment of the Crime of Genocide defines genocide more broadly than acts of killing, application of the term to Australia's history makes no sense to Clendinnen (and, she argues, to many others). She contends that 'the persistent invocation of the term "genocide"' has not only been 'ill-judged' but also a 'moral, intellectual and (as it is turning out) a political disaster'. ${ }^{44}$ As far as the short term goes, there is no gainsaying Clendinnen's contention regarding the political consequences. However, the concept of genocide, I am suggesting, might still be useful to us in the historical task of imagining and so understanding the past of our forebears (and therefore, in time, it might have beneficial political outcomes). There are too few historical studies that have methodically considered the implications of non-indigenous attitudes and approaches to Aborigines and Aboriginal affairs. It must be hoped that In denial or the subsequent debate will provoke historians to undertake these.

\section{Acknowledgements}

I am indebted to Liz Reed for her comments on a draft of this article. An earlier version appeared in the review section of the A ustralian Financial Review, 1June 2001.

\section{References}

Attwood, Bain 1996, 'Mabo, Australia and the end of history', in Bain Attwood (ed.), In the age of $M$ abo: history, A borigines and A ustralia, Sydney: 100-16.

— 2000, 'A matter for history', A ustralian Financial Review, 15 Dec.

— 2001, “'Learning about the truth": the Stolen Generations narrative', in Bain Attwood and Fiona Magowan (eds), Telling stories: Indigenous history and memory in A ustralia and N ew Z ealand, Sydney: 183-212, 241-60.

Barta, Tony 1987, 'Relations of genocide: land and lives in the colonisation of Australia', in Isidor Wallimann and Michael N. Dobkowski (eds), Genocide and the modern age: etiology and case studies of mass death, Westport: 237-51.

Black Inc 2001, Press release for the A ustralian Q uarterly Essay, Issue 1

Bolt, A ndrew 2001, 'At last a confession about the stolen "generations"', H erald Sun, 29 Mar.

Brunton, Ron 2001, 'The stolen reputation', A ge, 4 A pr.

Clendinnen, Inga 2001, 'First contact', A ustralian Review of Books, May: 6-7, 26.

Craven, Peter 2001, 'Introduction', in Robert Manne, 'In denial: the Stolen Generations and the Right', A ustralian Q uarterly Essay, Issue 1, Melbourne: iii-vi.

Curthoys, Ann 1997, 'Entangled histories: conflict and ambivalence in non-A boriginal Australia', in Geoffrey Gray and Christine Winter (eds), The resurgence of racism: $\mathrm{H}$ oward, $\mathrm{H}$ anson and the race debate, Mel bourne: 117-28.

43. Clendinnen 2001: 7, 26.

44. Clendinnen 2001: 7. 
Edwards, Coral and Read, Peter 1990 (eds), The lost children, Sydney.

Krygier, Martin 2001, 'Bringing it home to us', A ustralian Review of Books, June: 4.

Manne, Robert 1998, 'The Stolen Generations', in Peter Craven (ed.), The Best A ustralian Essays 1998, Melbourne: 23-36.

— 2001a, In denial: the Stolen Generations and the Right, Australian Quarterly Essay, Issue 1, Melbourne.

— 2001b, 'The journey of Manne', Sunday A ge, 27 May.

Moses, Dirk 2001, 'Blood curdling', A ustralian Review of B ooks, Jun: 4-5.

Read, Peter 1983a, ' "A rape of the soul so profound": some reflections on the dispersal policy in N ew South Wales', A boriginal History, 7(1): 23-33.

- 1983b, The Stolen Generations: the removal of A boriginal children in N ew South Wales 1883 to 1969 , Sydney.

Reynolds, Henry 2001, 'The Stolen Generations: truth, denial and conspiracies', A ge, 5 May.

Rintoul, Stuart 1993, The wailing: a national black oral history, Melbourne.

- 2001, 'Going Home', A ustralian M agazine, 21-22 A pr: 12-17.

Rowse, Tim 1989, 'A paler shade of dark: A boriginality, the Hasluck view', A ge M onthly Review , 8(10): 15-20.

Slattery, Luke 2001, A ustralian R eview of Books, May (front cover). 